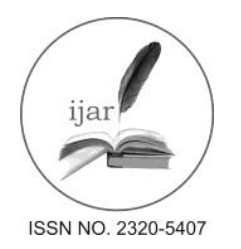

Journal homepage: http://www.journalijar.com
Journal DOI: $10.21474 /$ IJAR01

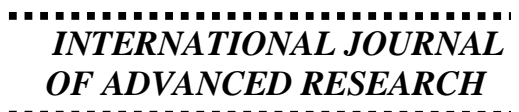

RESEARCH ARTICLE

\title{
AN OVERVIEW OF BACTERIAL BLIGHT DISEASE OF RICE CAUSED BY XANTHOMONAS ORYZAE PV. ORYZAE.
}

\author{
Ashwarya L. Tandon ${ }^{1} \&$ S. D. Chaliganjewar ${ }^{2}$. \\ 1. Department of Plant Pathology, College of Agriculture \& Research Station, Janjgir-Champa (C.G.)- 495668. \\ India. \\ 2. Department of Plant Pathology, Indira Gandhi Krishi Vishwavidyalaya, Raipur (C.G.)- 492006. India.
}

\section{Manuscript Info \\ Manuscript History: \\ Received: 19 March 2016 \\ Final Accepted: 26 April 2016 \\ Published Online: May 2016}

\section{Abstract}

Key words:

*Corresponding Author

Ashwarya L. Tandon.

Copy Right, IJAR, 2016. All rights reserved.

Rice is the most widely cultivated food crop of the world. Asia alone accounts for 90 per cent of the world's production coupled with consumption of rice also because of favorable hot and humid climate. Rice accounts for 3575 per cent of the calories consumed by more than 3 billion Asian (Khush, 2004). It is also expected that by the year 2050, 90 per cent of world's projected 11 billion people will reside in the developing countries (Krattigar, 1996). The production is constrained mainly due to biotic and abiotic stress. Major advances have occurred in food production during the last seven decades due to adoption of improved techniques including high yielding varieties. This has also lead to emergence of new pests and diseases simultaneously. The loss of the yield in all crops due to biotic stress is approximately 500 billion. It has been estimated that in bacterial blight of rice the yield losses are as high as 6 to 60 per cent depending upon location, season, weather condition and cultivars (Srivastava, 1967). Bacterial blight (BB) of rice, caused by Xanthomonas oryzae pv. oryzae (Xoo) reported as economically important disease in tropical Asia also (Mew, 1987 and 1989). The disease was known to occur in epidemic proportions in many parts of the world, incurring severe crop loss of up to 50 per cent. Crop loss assessment studies have revealed that this disease reduces grain yield to varying levels, depending on the stage of the crop, degree of cultivar susceptibility and to a great extent, the conduciveness of the environment in which it occurs.

Bacterial blight of rice is difficult to control through chemicals. Varietal resistance is considered the most practical and economic way of keeping the disease below the economic injury level. Variability in pathogenicity have now been fully recognized. Resistant varieties development has been targeted in almost all the breeding programmes of varietal improvement. In this context number of isogenic lines, differential having known genes and pyramids with more than two resistant genes have been also developed by different agencies. The literature pertaining to plant resistance and its nature of response in rice to Xanthomonas oryzae pv. oryzae has been reviewed under following heads: 


\section{Causal organisms:-}

The bacterial origin of the disease was first reported by Ishiyama in 1922. The disease was caused by the bacterium Xanthomonas oryzae pv. oryzae. The isolates and pathogenicity test of Xoo was first reported in India by Srinivasan et al. (1959).

\section{Taxanomy:-}

* The nomenclature of the causal bacterium has changed over the years as under.

* Bacillus oryzae Hori and Bokura, 1911.

* Pseudomonas oryzae Uyeda and Ishiyama, 1922.

* Bacterium oryzae (Uyeda and Ishiyama) Nakata, 1927.

* Phytomonas oryzae (Uyeda and Ishiyama) Dowson, 1939.

* Xanthomonas campestris pv. oryzae (Uyeda \& Ishiyama) Dye et al., 1980.

* Xanthomonas oryzae pv. oryzae (Ishiyama) Swings et al., 1990.

\section{Symptoms:-}

Bacterial blight was a vascular disease. The infection was therefore, systemic. The pathogen normally enters the host through wounds and or natural openings such as the water pores. In either case, the bacterium ends up in the xylem tissues, multiplies and moves throughout the plant (Mew, 1987). Three types of symptoms were reported on rice: Kresek, leaf blight and yellow leaf. 'Kresek' was the more destructive manifestation of the disease, wherein the leaves of the entire plant turned pale yellow and wilted during the seedling to the early tillering stage, resulting in a partial or total crop failure (Gnanamanickam et al., 1999). 'Leaf blight' is the most common disease symptom that occurs widely. Lesions on the leaf blades may extend to the leaf sheath. The lesion enlarges in length and width, and may have wavy margins. It turns a whitish-straw colour from its initial water soaked grayish or yellowish hue in 1-2 weeks. Bacterial ooze may be observed in humid and warm condition on the lesion. Leaf blight may occur at all growth stages, but, it is common from maximum tillering until maturity. 'Yellow leaf' was also considered a syndrome of bacterial blight (Ou, 1985). However, Mew (1987) considered this a secondary effect of kresek or leaf blight, apparently due to the effect of toxin produced by the bacteria rather than to interruption of nutrients from roots to shoots.

\section{Host range:-}

The weed hosts of Xanthomonas oryzae Japan were first reported under artificial inoculation (Goto et al., 1953), the infected weeds were also later found in nature. Togami and Mizukami (1962) reported that Leersia sayanuka Ohwi, was the most important as it served as a common over-wintering host. L. oryzoides (L) Sw., L. japonica and Zizania itifolia were also naturally infected. In the tropics, Leptochloa chinensis (L.), Ness L. filiformis and L. panacea had been found weed host in the Philippines Cyprus rotundus L. and C. defformis were also reported from India as being alternative host found under natural conditions (Chattopadhyay and Mukherjee, 1968).

\section{Variability:-}

For many years, it was unclear whether there was differential interaction between rice and Xoo. Many scientist opinions differed on the existence 'races' of the bacterial blight of rice pathogen. The confusion was centered on the question of a system that could clearly differentiate pathogenicity of bacterial pathogen. With two different cultivars and two different isolates, scientists often looked for the host pathogen association, when the disease was either present or absent in the cultivars isolates combinations. Resistance in rice to $X$. oryzae pv. oryzae was therefore often viewed in the absolute rather than in the relative terms, neither pathogenic specialization nor specific resistance occurs alone.

\section{Variation in pathogenicity:-}

The degree of specialization reported to differs in various host-pathogen associations (Browder and Eversmeyer, 1986). Variation in the virulence of Xoo from one location to another location and from one country to another (particularly in Asia) has long been recognized (Buddenhagen et al., 1969; Buddenhagen and Reddy, 1972; Kauffman and Rao, 1972; Reddy and Ou, 1976; Mew and Vera Cruz, 1979, 1988; Srinivasan and Singh, 1982; Durgapal, 1986; Gupta et al., 1986; Noda et al., 1990; Gopinath et al., 1991; Nayak and Reddy, 1993). Isolates from India have been reported more virulent than the isolates from Japan (Wakimoto, 1967; AICRIP, 1971; Reddy, 1980; Nayak and Reddy, 1993). Since the breakdown of resistance, scientist from Japan made attempts to classify rice varieties and bacterial isolates in Japan (Kuhara et al., 1965; Washio et al., 1966 and Ezuka and Horino, 1974). 
Kozaka (1969) presented a system of varietal classification. On the basis of differential reaction, rice varieties were derived into four groups viz., Kinmaze, Kogyoku, Rantjemas and Wase Aikoku. The bacterial isolates were put into three groups I, II and III accordingly. Devdath and Padmanabhan (1969) tested nine isolates on 20 cultivars and found differences in virulence. They noticed that cultivars resistant in Japan or in Philippines became susceptible in India and found differential interaction between isolates and cultivars. Xia and Fu (1983) studied variability and strain separation of Xoo in 1979-83. Nearly 200 isolates of the bacterium from rice in each major epidemic region of 46 countries and cities in Fujian province were tested on set of differentials in China and some differential cultivars from Japan and IRRI with known resistance genes. Results showed that the Fujian isolates differed in virulence from strains in Japan and Philippines. Some cultivars including Jiggang 30, Zaiyequing 8, Honken 57, Zhike, Nan 15, IR26 and 76 C-Fan 7 could be used as a set of differentials in Fujian to classify 5 strain groups (0, I, II, III and IV) and 9 sub groups. Noda et al. (1990) distinguished seven races in Japan using five Japanese differential, but when they used 18 differential varieties, from several Asian countries including Japan, race I, II and III could be subdivided further into 10, 17 and 13 subgroups respectively. Five cultivars (Chugoku 45, IR 20, Tongil, Milyang 42 and DV 85) were resistant to all the isolates tested. Studied at All India Co-ordinated Rice Improvement Projects (AICRP) had showed the existence of only two pathotypes. Pathotype I was prevalent in all the bacterial blight epidemic regions of the country whereas, distribution of pathotype II was restricted to areas in Orissa and West Bengal (Reddy, 1980). Durgapal (1986) obtained the isolates from rice in the epiphytic year. On the basis of reaction on BJ1, TKM-6, T-65, and T(N)-1, the isolates were made differential into five pathogenic groups designated pathotypes I, II, III, IV and V. Reddy and Reddy (1990) collected, 130 isolates of Xoo from 25 locations from different regions of India, where bacterial blight of rice was endemic and grouped into pathotypes Ia, Ib and II based on the reactions on six differential cultivars. Gopinath et al. (1991) tested the pathogenicity of 12 of 37 isolates of Xanthomonas oryzae on 17 rice cultivars. All the 12 isolates were virulent on all cultivars tested. Pathotypes studies conducted under the All India Co-ordinated Rice Improvement Project (AICRIP) had identified two major pathotypes within the Xoo populations in India (Reddy and Reddy, 1992). Das et al. (1994) reported isolate HC 44, which was most virulent out of four different isolates of the bacterial blight pathogen tested. This isolate produced early infection and large lesions on the leaves during their testing. Nayak and Reddy (1993) constituted a set of differentials comprising in rice varieties IR-8, IET-8585, PN-13, TKM-6 and DV-85 and/ or Malagkit Sungsong to classify the isolates of bacterial blight pathogen occurring in India into virulence groups. Based upon the reaction, 36 bacterial isolates (CR x CO1 - CR x CO36) were distinguished into 6 groups or pathogens. The DV-85 showed resistance against Indian group I, III, IV and IR-8 showed susceptibility against all isolate groups (I-IV). Thrimurty et al. (1993) isolated 6 isolates $(6,6 \mathrm{R}, 6-4 \mathrm{R}, 6-5 \mathrm{R}, 6-6 \mathrm{R}$ and 6-7R) of Xanthomonas oryzae from rice in different parts of Chhattisgarh region. These isolates showed variations in their reaction on isogenic lines, differential varieties and MP rice germplasm genotypes. They found that isolate 6-5R and 6-4R were most virulent. Among the isogenic lines, IRBB$1(\mathrm{t})$ was resistant against isolate $6 \mathrm{R}, 6-5 \mathrm{R}$ and 6-7R. Among the differential varieties, BJ-1, IR-20, IR-13427 and IR1543-338 were resistant against three isolates. Isolate 6-5R showed virulent reaction on maximum number of differentials followed by 6-4R. All the isolates showed variable disease reaction on the Madhya Pradesh germplasm rice genotypes. BJ-400-1 and RP-2151-33-2 were found resistant against maximum number of isolates (4). The overall reaction of the isolates on the 48 varieties (10 isogenic + 24 differential + 14 MP germplasm) showed that isolate 6-5R was avirulent on only two varieties [IRBB-1(t) and S-971] followed by 6-4R on 4 varieties (BJ-400-1, RP-2151-33-2, BJ-1 and IR-24). IRBB-1 was resistant against isolate 6R.

\section{Isolation, purification and testing the pathogenicity:-}

The isolates of Xanthomonas oryzae were recovered from infected rice samples. The causal bacterium was isolated from green leaves with yellow BB young lesions. The bacterial exudates from fresh lesion were better isolation material as compared to infected tissue because of less contamination. This was also observed by Isaka (1970). Ishiyama (1922) reported Xanthomonas oryzae pv. oryzae to be associated with bacterial blight of rice. It was first time isolated in 1884 from Japan. The media used for isolation were yeast extract dextrose calcium carbonate agar medium (YDCA), Wakimoto semi synthetic agar (WSSA) and Nutrient agar (NA). The Xanthomonad produced yellow, mucoid, dome shaped, shiny colonies on YDCA medium. These cultural characteristics corresponds to the results of Lelliot and Stead (1987). The bacterium when grown on WSSA medium produced viscous, smooth, circular colonies. Similar results had been reported by Wakimoto $(1955,1967)$. On NA medium the bacterium produced light yellow, circular dome shaped colonies. The yellow colour and mucoid colonies were cultural characteristics of Xanthomonads due to the production of extra cellular polysaccharides (EPS in media containing sugar). Ou (1977) observed lesions on upland rice as well as on weeds both near to and far from rice fields in several Latin American countries. He suspected that the causative agent was similar to Xoo, but this was not confirmed by isolation, pathogenicity or other bacteriological tests. Lazano (1977) isolated a bacterial pathogen from infected rice 
in the Caribbean region and identified it as Xoo. No further reports of BB in the American continent emerged until July 1987, when a rice disease exhibiting symptoms similar to those of bacterial blight was observed in Taxas and Louisiana in the United States. Bacterial isolates from infected tissues showed the cultural and bacteriological characteristics and pathogenicity of Хoo. This was perhaps the first time the disease was reported in the US. In India, bacterial blight was first isolated from diseased leaves by Srinivasan et al. (1959) at Bombay region in 1951. Dinh et al. (2008) collected diseased rice leave samples from 13 provinces, used for isolation and evaluated for the variation in pathogenicity. Forty one isolates were used for inoculation on 10 differential rice varieties containing different single resistant genes, the results showed that the infection response was clearly compatible and incompatible reactions on differential rice varieties. Gene xa 5 was highest effective against the disease, the next were Xa 7 , Xa 21 and xa 13. Six pathogenic races were identified and their distribution was varied across the provinces in Mekong Delta. Race A, E and F were predominant, they occurred and infected on rice in 6 to 8 provinces, while race B, C and D in 3 to 5 provinces in Mekong Delta. Khan and Hingorani (1970) studied the pathogenicity of Xanthomonas oryzae pv. oryzae by three methods of inoculation viz., clipping, pin-prick and paint brush were tested both on detached leaves and on attached leaves in-vitro and in-vivo. They observed all the three methods were effective for artificial inoculation, but pin-prick method was found to be more efficient in detached leaf assay (in-vitro) based on lesion size. The paint brush method of inoculation was found to be less effective as compared to other two methods but it was more similar to natural infection. Mew et al. (1981) compared the needle prick, clip and spray technique and found that neither lesion length nor disease score were affected by inoculation method, although the incubation period was longer in spray inoculated plants than in other plants. The pin-prick method of inoculation developed by Muko and Yoshida (1951) and Yoshida and Muko (1961) proved most suitable for quantitative determination of causal bacterium. The cell sap coming from injured tissue due to pin-pricking usually serves as nutrient for the bacteria. This causes bacterium to multiply and increase in hypertrophic region. After that the bacterium moves towards non-hypertrophoic intercellular spaces. Kauffman et al. (1973) proved that the clipping method of inoculation was quick and efficient in glass house and field assay. The leaves of each plant are grasped and the top of the leaves were clipping by a pair of scissor dipped in bacterial suspension. The cut ends provide entry for pathogen and might be one of the main causes for spreading BB disease in rice plans. Ogawa et al. (1990) used the clipping inoculation method for their genetic studies and found this method most efficient for genetic analysis of resistance cultivars.

\section{Age factor influence on resistance:-}

A varied response of rice plant to Xanthomonas oryzae pv. oryzae at different growth stages has been reported. Crop growth stages with reference to resistance were studied by few research workers. Mew et al. (1981) reported that leaf and plant age influenced the infection which varied from young to old plants. Noda (1982) observed that the reaction of cultivars at different growth stages found to be helpful in classifying the pathogen isolates into different groups. The disease pressures at adult stages were lower than that recorded at the seedling stage. Kinmaza, Sigadagabo, Tetep and Nagomasari were selected to classify bacterial isolates into four groups by artificial inoculation at the seedling stage. Hossain et al. (1982) developed 39 mutant strains through gamma rays irradiation and EMS treatment of the rice cv. Nizersail and evaluated for resistance to Xanthomonas campestris pv. oryzae at seedling, maximum tillering and flowering stages. Disease severity increased with age in both the mother cultivar and the mutant strain. Sharma et al. (1982) studied both seedling resistance and adult plant resistance among the 428 cultivars. Resistance at both the stages was associated with the genes Xa 1, Xa 2, Xa3 and Xa 5, whereas, cultivar IR 20 carrying Xa 4 gene was susceptible at both the stages. Few of the cultivars tested were resistance either at seedling stage or during the adult plant. In contradiction to the previous finding Zhang et al. (1984) observed in a study of 11 varieties with adult plant resistance to Xanthomonas oryzae, one with overall resistance and one with susceptibility, the responses of those with adult plant resistance changed from susceptible to resistant in the 55-68 the days of the growth period. The varieties differed in their response to the three isolates used, some showing adult plant resistance to same isolates and overall resistance to others. Qi and Mew (1985) reported that selected rice cultivars expressed more resistance to Xanthomonas campestris pv. oryzae as plants advanced in age, this being comparable with adult plant resistance to diseases in other crops. Some cultivars were resistant to four races and other to only one or two and the disease severity on some cultivars gradually decreased from seedling to the flag leaf, whereas, in others it showed a distinct change to a resistant reaction on a certain leaf. The leaf showing resistance varied with cultivars. Wase Aikoku 3 had adult plant resistance to three races, but seedling resistance to another. The adult plant resistance of rice to bacterial blight appears to be race specific. Similar findings were also reported by Yoshimura et al. (1985). Guo et al. (1987) tested 36 varieties by inoculating with Xanthomonas campestris pv. oryzae strain KS-6-6. Among these, 6 indica varieties showed resistance throughout the growth period; 5 indica and 5 japonica varieties were susceptible throughout the whole season and 4 indica and 16 japonica 
varieties showed adult plant resistance. These findings revealed in the resistance expressed in different ways. This was clearly depicted in Yangeng 2 and Dazhi 1 which were resistant from the 7 to 8 leaf stage, Nangeng 11 was only fully resistant after the 11 to 12 leaf stage. Liu (1990) studied 24 varieties throughout their development, some had a clear stage of adult plant resistance to Xanthomonas campestris pv. oryzae, while others developed the infection gradually. In some varieties, adult plant resistance was shown only to certain strains of the pathogen. Sahu (1987) screened about 200 rice cultivars and some hybrid progenies against Xanthomonas campestris pv. oryzae for resistance at the seedling, maximum tillering and boot leaf stages. Plants that were resistant to the disease at the seedling stage remained resistant at later growth stages, but the reverse was not true. Identification of resistant plants at the seedling stage was possible if the genotypes involved possessed the Xa 5 and or Xa 10 resistance genes. Plants with Xa 4 conferred resistance at the maximum tillering stage, while cultivars possessing Xa3 genes could only be identified at the boot leaf stage. Therefore, it was recommended that cultivars be screened at the all stages. Sahu (1988) screened 200 rice cultivars from the IRRI gene bank at seedling, maximum tillering and boot stage. Resistances at tillering and panicle initiation stages were closely linked in some of the cultivars. Noda and Ohuchi (1989) extensively studied, involving a wide range of varieties, and reported information on differences in varietal resistance to the pathogen during the seedling stage, genetic analysis of resistance to the pathogen in varieties during both the seedling and adult plant stages, classification of isolates of the pathogen on the basis of virulence to varieties at the seedling stage and interaction between the kresek and leaf blight phases of bacterial blight of rice. Koch and Mew (1991a) observed that lesions of all cultivars decreased about equally in absolute length with plant age, but the relative increase in lesion length was greater with moderately resistant cultivars than with highly susceptible. The change in quantitative resistant cultivars with increasing plant age was different. The resistance immature leaves that were still extending showed susceptibility than the adjacent mature, fully expanded leaves, but immature leaves of moderately resistant cultivars were less susceptible than those of highly susceptible cultivars. Koch and Mew (1991b) reported that younger plants and susceptible cultivar had higher rates of increase than older plants and moderately susceptible cultivars, respectively. The rate of expansion of Xanthomonas campestris pv. oryzae decreased with time, for strains PXO 71 and PXO 99 and increased or remained the same for strains PXO 86. There were no major differences among cultivars for the change in the rate of lesion expansion over time. The susceptible cultivar IR-24, which was used as susceptible control in screening trial displayed resistance at adult plant growth stage. Further, resistance conveyed by Xa 21 was evident in 21 days old plants, and the level of resistance increased with plant maturity (Mazzola et al., 1994). Goel and Singh (1995) examined 27 genotypes at three growth stages (seedling, tillering and flowering), and among them the BR-51, 50-3-4, IETS 8326 and IETS 12174 showed overall resistance to all five pathotypes of Xanthomonas oryzae pv. oryzae and others showed adult plant resistance to one or more pathotypes. The expression of adult plant resistance was both cultivar and pathotype specific. Resistance at the seedling stage did not change to susceptibility at later growth stages in any of the cultivar / pathotype combinations studied. Malagkit Sungsong, Zenith, IR-944 and IR-1695, possessing Xa 6 gene conferring resistance to Xanthomonas oryzae were susceptible at the seedling stage but resistant at the leaf stages of 11 and 12. Malagkit Sungsong showed resistance on earlier leaves than did the other cultivars. On staggering the planting to synchronize inoculation, resistance increased with ascending leaf position. Lesions on susceptible $\mathrm{T}(\mathrm{N}) 1 \mathrm{developed}$ faster at 33/25 $\square \mathrm{C}$ than at 25/20 $\square \mathrm{C}$. The overall resistance of IR1545-339 was not altered by high temperature. The adult plant resistance of the cultivars tested was not affected by changes in temperature. The bacterial population in leaves 6, 9 and 10 of the variety Zenith was at a maximum three days after inoculation; on leaf 12 the population was lower (Qi and Mew, 1984). The degree of infection was studied at early tillering, maximum tillering and booting in 12 rice varieties carrying Xa 4 resistance gene, after inoculation in dry season with races 1 and 2 of Xanthomonas campestris pv. oryzae. Based on hill infection, the relative resistance index (calculated by comparison with susceptible cv. IR-24) of the varieties infected with race 1 (avirulent) increased as the plant matured. The same occurred with race 2 (virulent). It was suggested that these varieties contain background resistance in addition to Xa4 and increased as the plant matures (Mew and Vera Cruz, 1988). The early japonica lines G 38, carrying the gene Xa 5 for resistance to Xanthomonas campestris pv. oryzae, was used as resistance donor in crosses with the recurrent parent Xiushui 11, which had adult plant resistance. As a result of successive backcrosses, three late japonica lines, D601, D602 and D603, were bread with resistance at all stages. Genetic analysis showed that the lines combined with gene Xa 5 and Xa 3 were more resistant than G 38 and Xiushui 11 (Xu et al., 1996). Khare and Thrimurty (2006) evaluated 86 cultivars in 1999 and 2000 for resistance to Xanthomonas oryzae pv. oryzae at the seedling, maximum tillering and flowering stages. At the seedling stage, disease incidence ranged from $6.2 \%$ (IR54/BK-1170-33-13-1-1-32) to 1.6\% (R-714-1-19-1-7). At the maximum tillering stage, disease incidence ranged from $1.9 \%$ (R 296-260) to $0.3 \%$ (IRBB-207) and at 50\% flowering stage, the disease incidence ranged from $0.6 \%$ (R 435-1585) to $10.8 \%$ (RP-2526-14767-1143) among the cultivars studied. Thrimurty et al. (2000) studied Ajaya (IET-8585) bacterial blight resistance variety possessing donor level resistance. They observed out of the inoculated 
leaves, 48 per cent showed resistant, 42 per cent moderate and 10 per cent susceptible reaction. Only 7 per cent leaves showed water soaked symptom irrespective of lesion length. Narrow broken lesions were also observed with intermediate healthy area in 6 per cent leaves. The AUDPC values of the inoculated leaves showed that $2^{\text {nd }}$ leaf was more prone to blightening than younger first leaf. The susceptible check TN-1 showed 100 per cent susceptibility with water soaked and no broken lesions during the same period. Thrimurty et al. (2005) studied 65 rice genotypes developed from MAS. The composition of the genotypes were xa 5 (6 entries), xa 13 (6 entries), Xa 21 (6 entries), xa $5+$ xa 13 (5 entries), xa $5+$ Xa 21 (5 entries), xa $5+$ xa $13+$ Xa 21 (17 entries). Variation in disease reaction among the MAS selected plants of a genotype were also recorded ranges from susceptible to resistant reaction. They further ascribed that the virulence of the pathogen and congenial condition, does play more importance for such variations. Similarly, in other crops also the host pathogen interaction was studied.

\section{References:-}

1. AICRIP. 2002-2007. Annual Progress Report for 2002-2006. All India Co-coordinated Rice Improvement Project, Hyderabad, India.

2. Browder, L. E. and Eversmayer, M. G. 1986. Parasite: Host specificity and resistance/susceptibility, two concepts, two perspectives. Phytopathol., 76: 379-381.

3. Buddenhagan, I.W. and Reddy, A.P.K. 1972. The host, the environment, Xanthomonas oryzae and researches. In: Rice Breeding International Institute, Los Banos, Manila, Philippines. pp.289-295.

4. Buddenhagen, I. W.; Silva, I.P. and Ou, S. H. 1969. First year report of the cooperative project on comparison of the virulence of Xanthomonas oryzae strain from different Asian countries. University of Hawaii, Honolulu.

5. Chattopadhyay, S B. and Mukharjee, N. 1968. Occurrence in nature of collateral hosts of Xanthomonas oryzae incitant of bacterial blight of rice. Curr. Sci., 57: 441-442.

6. Das, B. C.; Bora, L.C. and Bhagbati, K. N. 1994. Interaction of virulent and avirulent isolates of Xanthomonas oryzae pv. oryzae with rice chloroplast, variation in lesion development and electrolyte leakage. Indian $\mathrm{J}$. Mycol. Pl. Pathol., 4(1): 29-32.

7. Devadath, S. and Padmanabhan, S. Y. 1969. A preliminary study on the variability of Xanthomonas oryzae in some rice cultivars. Plant Disease Reporter, 53: 145-148.

8. Dinh, H. D.; Oanh, N. K.; Toan, N. D.; Van Du, P. and Le, C. L. 2008. Pathotype profile of Xanthomonas oryzae pv. oryzae isolates from the rice ecosystem in Cuulong rever delta. Omonrice, 16: 34-40.

9. Dowson, W. J. 1939. Bacterial Disease In: Rice Disease Common Wealth Mycological Institute Kew Survey, $2^{\text {nd }}$ ed. England. pp. 61.

10. Durgapal, J.C. 1986. Relation between panicle infection and severity of bacterial blight of rice under field conditions. Indian Phytopath., 39(4): 581.

11. Dye, W.; Bradbury, J.F.; Goto, M.; Hayward, A. C.; Lelliot, R. A. and Schroth, M. N. 1980. International standard for naming pathovars of phytopathogenic bacteria and a list of pathovar names and pathotype strains. Rev. Pl. Pathol., 59: 153-168.

12. Ezuka, A. and Horino, O. 1974. Classification of rice varieties and Xanthomonas oryzae pv. oryzae strains on the basis of their differential reaction. Bulletin Tokai-Kink; National Agricultural experiment station. 27:19.

13. Gnanamanickam, S. S.; Brindha, P. V.; Narayan, N. N. and Kavitha, S. 1999. An overview of bacterial blight disease of rice and strategies for its management. Curr. Sci., 77:1435-1444.

14. Goel, R. K. and Singh, P. 1995. Characterization of resistance to bacterial blight (Xanthomonas oryzae pv. oryzae) in some rice genotypes. Plant Dis. Res., 10(1): 16-21.

15. Gopinath, S.; Gnanaguru, M. and Naidu, M. V. 1991. Pathogenic races of Xanthomonas campestris pv. oryzae. IRRI News letter, 156 (3): 12-13.

16. Goto, K.; Fuktatzu, R. and Okata, K. 1953. Over-wintering of the causal bacteria of rice blight in the rice plant and grasses. Preliminary Report. Agril. Hort. Tokyo., 28: 207-208.

17. Guo, C. J.; Deng, X. R. and Zhang, C. P. 1987. Adult plant resistance to Xanthomonas campestris pv. oryzae in rice. J. Agric. Sci., 3(1): 25-30.

18. Gupta, A. K.; Sharma, S. C. and Saini, R. G. 1986. Variation in pathogenicity of some Indian isolates of Xanthomonas campestris pv. oryzae. Phytopathol., 76: 881-883.

19. Hori, S. and Bokura, A. 1911. Bacterial Disease In: Rice Disease Common Wealth Mycological Institute Kew Survey, $2^{\text {nd }}$ ed. England. pp. 61.

20. Hossain, I.; Jalaluddin, M. and Miah, A. J. 1982. Studies on bacterial blight reaction in mutant strains of rice. Int. Rice Commi. Newsletter, 31(1): 44-49.

21. Isaka, M. 1970. A new detection method for the pathogen of bacterial blight of rice (Xanthomonas oryzae pv. oryzae) by means of bacterial exudation. Ann. Phytopathol. Soc. Jpn., 36: 313-318. 
22. Ishiyama, S. 1922. Studies on Bacterial blight. Report Agr. Expt. Sta., 45: 233-261.

23. Kauffman, H. E. and Rao, R. S. 1972. Resistance to bacterial blight in India. In Rice Breeding, International Rice Research Institute, Los Banas, Philippines. pp.283-287.

24. Kauffman, H.E.; Reddy, A.P.K.; Heish, S.P.Y. and Marca, S.D. 1973. An improved technique for evaluating resistance of rice varieties to Xanthomonas oryzae. Plant Dis. Rep., 57: 537-541.

25. Khan, S. and Hingorani, I. H. 1970. Phenotypic correlation ananlysis of elite F3:4 Brassica populations for qualitative and quantitative traits. Journal of Agricultural and Biological Science, 3(1):1990-2011.

26. Khare, N. and Thrimurty, V. S. 2006. Stage-specific resistance in rice Xanthomonas oryzae pv. oryzae. Ann. of Plant Protection Science, 14(2): 511-512.

27. Khush, G. 2004. Harnessing Science and technology for sustainance rice based production systems. FAO Rice Conference 2004 CRS, 14: 1-12.

28. Koch, M. F. and Mew, T. W. 1991a. Effect of plant age and leaf maturity on the quantitative resistance of rice cultivars to X. c. pv. o. Plant Dis., 75: 901-904.

29. Koch, M. F. and Mew, T.W. 1991b. Rate of lesion expansion in leaves as a parameter of resistance to Xanthomonas compestris pv. oryzae in rice. Plant Dis., 75: 897-900.

30. Kozaka, T. 1969. Control of rice disease with resistant varieties. Agriculture and Horticulture, 44: $208-212$.

31. Krattigar, A. F. 1996. The role of private sector in biotechnology. International Conference, Sasktomy. pp. 143144.

32. Kuhara, S.; Kurita, T.; Tagami, Y.; Fuji, H. and Anseikiya, N. 1965. Studies on the strain of Xanthomonas oryzae (Uydea et Ishiyama) Dowson, the pathogen of the BB of rice with special reference to its pathogenicity and phage sensitivity. Bulletin Kyushu Agricultural Experiment Station. 11: 263-312.

33. Lazano, J. C. 1977. Identification of bacterial blight in rice caused by Xanthomonas oryzae in America. Plant Dis. Rep., 61: 644-648.

34. Liu, H. X. 1990. Resistance of rice varieties to bacterial blight at different stages of development. Crop Genet. Resources. 1: 19-20.

35. Mazzola, M.; Leach, J. E.; Nelson, R. and White, F.F. 1994. Analysis of the interaction between Xanthomonas oryzae pv. oryzae and the rice cultivars IR-24 and IRBB-21. Phytopathol., 84(4): 392-397.

36. Mew, T. W. 1987. Current status and future prospects of research on bacterial blight of rice. Ann. Rev. Phytopathol., 25: 359-382.

37. Mew, T. W. 1989. An overview of the world bacterial blight situation. Bacterial blight of rice. International Rice Research Institute. P.O. Box. 933. Manila, Philippines. pp. 7-12.

38. Mew, T. W. and Vera Cruz, C. M. 1979. Variability of Xanthomonas oryzae: specificity in infection of rice differentials. Phytopathol., 69 : 152- 155.

39. Mew, T. W. and Vera Cruz, C. M. 1988. Background resistancce to bacterial blight (BB) hill and leaf infection. Int. Rice Res. Newsletter, 13(2): 11-12.

40. Mew, T. W.; Vera Cruz, C.M. and Reyes, R.C. 1981. Characterization of resistance in rice to bacterial blight. Ann. Phytopathol. Soc. Japan, 47(1): 58-67.

41. Moko, H. and Yoshida, K. 1951. A needle inoculation method for bacterial blight disease of rice. Ann. Phytopathol. Soc. Jpn., 15: 179.

42. Nakata, P. 1927. Bacterial Disease In: Rice Disease. Common Wealth Mycological Institute Kew Survey, $2^{\text {nd }}$ ed. England. pp. 61

43. Nayak, D. and Reddy, P. R. 1993. Classification of rice varieties and isoalates of bacterial blight pathogen on the basis of differential interaction. Oryza, 30: 268-271.

44. Noda, T. 1982. Difference in resistance of rice varieties to Xanthomonas campestris pv. oryzae at seedling stage. Proc. Assoc. Plant Prot. Hokuriku, 30: 34-39.

45. Noda, T. and Ohuchi, A. 1989. A new pathogenic race of Xanthomonas campestris pv. oryzae and inheritance of resistance of differential rice variety, tetep, to it. Ann. Phytopathol. Soc. Japan, 55: 201-297.

46. Noda, T.; Horino, O. and Ohuchi, A. 1990. Variability of pathogenicity in races of Xanthomonas campestris pv. oryzae in Japan. Japan Agricultural Research Quartely, 23(3):182-189.

47. Ogawa, T.; Yamamoto, T.; Khush, G. S. and Mew, T. W. 1990. The relationship between genes xa-3 and xa-6 for resistance to rice bacterial blight. Rice Genet. Newsl., 3: 80-82.

48. Ou, S. H. 1977. Possible presence of bacterial blight in Latin America. Int. Rice Res. Newsl., 2(2): 5-6.

49. Ou, S. H. 1985. Rice Diseases Common Wealth Mycological Institute, Kew, England. $2^{\text {nd }}$ Ed. pp: 380.

50. Qi, Z. and Mew, T. W. 1985. Adult-plant resistance of rice cultivars to bacterial blight. Plant Dis., 69(10): 896898. 
51. Reddy, A. P. K. 1980. A report on bacterial blight epidemics in Punjab state. All India Co-ordinated Rice Improvement Project, Rajendra Nagar, Hyderabad.

52. Reddy, M. T. S. and Reddy, A. P. K. 1990. Variability in Xanthomonas oryzae pv. oryzae and their relationship to physiological character. Ann. Agric. Res., 11: 283-290.

53. Reddy, M. T. S. and Reddy, A. P. K. 1992. Occurrence of pathotypes of X. campestris pv. oryzae in India. Indian J. Mycol. Pl. Pathol., 22: 205-206.

54. Reddy, O. R. and Ou, S. H. 1976. Pathogenic variability in Xanthomonas oryzae. Phytopathol., 66: 903-906.

55. Sahu, R. K. 1987. Evaluation for bacterial blight resistance at different growth stages of the plant. Oryza, 24(4): 396-397.

56. Sharma, S. C.; Saini, R. G. and Gupta, A. K. 1982. Resistance of rice cultivars to Xanthomonas campestris pv. oryzae at seedling and adult stages. Int. Rice Res. Newsletter, 7(4): 5-6.

57. Shrivastava, D. N.; Rao, Y. P.; Durgapal, S. C.; Jindal, J. K. and Singh, W. 1959. Screening of rice varieties for resistance to bacterial blight. Indian Farming, 17: 25-28.

58. Srinivasan, M.C.; Thirumalachar, M.T. and Patel, M.K. 1959. Bacterial blight of rice. Curr. Sci., 28:

59. Srivastava, D.N. 1967. Epidemiology and control of bacterial blight of rice in India. In Proceeding: symposium on rice disease and their control by growing resistant varieties and other measures, Ministry of Agriculture and Forestry, Japan, Sept. 25-28, $\mathrm{A}_{1}-\mathrm{A}_{15}$.

60. Swings, J.; Vanden M.M.; Vauterin, L.; Home, B.; Gillis, M.; Mew, T. W. and Kersters, K. 1990. Reclassification of the causal agents of bacterial blight (Xanthomonas campestris pv. oryzae) and bacterial leaf streak (Xanthomonas campestris pv. oryzicola) of rice as pathovers of Xanthomonas oryzae (ex. Ishiyama, 1922) sp. nov. nom. rev. International Journal of Systematic Bacteriology, 40: 309-311.

61. Tagami, Y. and Mizukami, T. 1962. Historical review of the researches on bacterial blight of rice caused by Xanthomonas oryzae (Uyeda and Ishiyama) Dowson. Special Report Plant Disease and Insect forecasting Service. pp:10-112.

62. Thrimurty, V.S.; Kumar, A.; Lakpale, N.; Agrawal, K.C.; Kotasthane, A.S. and Srivastava, M.N. 1993. Pathogenic variability of Xanthomonas campestris pv. oryzae in Chhattisgarh region of India. Oryza, 30(3): 239-244.

63. Thrimurty, V.S.; Kumar, R.; Lakpale, N. and Agrawal, K.C. 2000. Variation in host-pathogen interaction in a resistant rice variety to Xanthomonas oryzae pv. oryzae. In preceedings: International Conference on Integrated Plant Disease Management for Sustainable Agriculture, New Delhi. 2: 1139-1140.

64. Wakimoto, S. 1955. Overwintering of Xanthomonas oryzae in unhulled grain of rice. Agric. Hortic. (Tokyo) 30: 1501.

65. Wakimoto, S.1967. Strains of Xanthomonas oryzae pv. oryzae in Asia and their virulence against rice varieties. Rice diseases and their control by growing resistant varieties and their measures. Trop. Agric. Res., Japan. pp19-24.

66. Washio, O.; Kaurya, K. and Toriyama, K. 1966. Studies on breeding of rice varieties for resistance to bacterial blight. Bulletin of the Chugoku Agricultural Experiment Station. 13: 55-85.

67. Xia, Y. H. and Fu, S.H. 1983. Studies on variability and strain separation of Xanthomonas campestris pv. oryzae. Journal Fujuan Agriculture College, 13(1): 124-127.

68. Xu, J. L.; Lin, Y. Z.; Weng, J. P. and Zhao, X. L. 1996. Convergence of genes for resistance to bacterial blight in rice and its genetic effect. Acta Agronomic Sinica, 22(2): 129-134.

69. Yoshimura, A.; Omura, T.; Mew, T. W. and Khush, G. S. 1985. Genetic behaviour of resistance to bacterial blight in differential rice cultivars in the Philippines. Bull. Inst. Trop. Agric., Kyushu University, 8: 1-54.

70. Zhang, D.P.; Xie, Y.F. and Mew, T.W. 1984. Studies on adult plant resistance to bacterial blight in rice. Scientia Agricultura Sinica, 1: 40-50. 